\title{
Community gardening in Stockholm: participation, driving forces and the role of the municipality
}

\author{
Madeleine Bonow* and Maria Normark \\ School of Natural Sciences, Technology and Environmental Studies, Södertörn University, Stockholm, Sweden \\ ${ }^{*}$ Corresponding author: madeleine.bonow@sh.se
}

\author{
Accepted 8 December 2017; \\ First published online 15 January 2018
}

Themed Content: Critical Foodscapes

\begin{abstract}
The paper reports on a study of community gardening in Stockholm. We contribute to the body of knowledge about the sustainability of community gardens and this new form of citizen-led initiatives in Stockholm, with the ambition of creating a debate about the best way to sustain and develop these initiatives in Sweden. We argue that although community gardening may provide leverage for means of developing a sustainable city, it is a marginal phenomenon and contributes little to sustainable development its present form. Through interviews we have investigated how the citizens and municipality officers of Stockholm try to adapt to the renewed interest in community gardening by looking at the policy makers', municipality officers' and grassroots movements' incentives to start community gardens. We specifically focus on how the community gardeners articulate their reasons for participating in collaborative initiatives in the city and how these expectations evolve when they are faced with the reality of gardening and the problems relating to producing food in the city. We have found that there are a growing number of citizens and local authorities advocating community gardening, but the sustainability and endurance of gardens are hampered by vague responsibilities, lack of leadership and unclear expectations of the outcome. Community gardening cases in Stockholm contribute to the debate by exemplifying how formal (e.g. policy making) and informal advocacy (e.g. civic engagement in community gardening) groups are collaborating, but also showing that they often have different agendas and initial motivations for setting up new gardens. We argue that uncritical enthusiasm results in an overly instrumental approach to governance of community gardening and that the sustainability and endurance of the community gardening is not an issue that the governing bodies plan for, and hence it is forgotten. We suggest some routes forward, involving employing facilitators from various stakeholders such as the municipality, housing companies and various NGOs.
\end{abstract}

Keywords: Community gardening, Stockholm, sustainability

\section{Introduction}

The paper reports on a study of community gardening in Stockholm. We will contribute to the debate on the sustainability of community gardens and this new form of citizen-led initiatives in Stockholm, with the ambition of creating a debate about the best way to sustain and develop these initiatives in Sweden. We argue that the developing practices surrounding this new wave of community gardening are important to study because the driving forces of participation may teach us important lessons regarding incentives for urban development that incorporate sustainability. This move is essential, not least given that the United Nation's Sustainable Development Goals stress the importance of access to green environments as well as responsible consumption and production. This paper explores the emergence of community gardening initiatives as a form of Urban Agriculture in Stockholm and scrutinizes it by looking at the citizens' planning initiatives and the local administrations' attitudes towards community gardening. Of particular interest are the motives and outcomes of such initiatives.

\section{The new wave of gardening in the city}

All over the world, cities are facing intense pressure to engage in sustainable development agendas, both from higher policy levels as well as from citizens (Evans et al., 2002; Bulkeley and Castán Broto, 2013; McCormick et al., 2013). However, as Hajer and Wagenaar (2003, p. 3) explain, governments often face 'open-ended, 
unusual, ad hoc arrangements' when seeking to promote sustainability as a goal (e.g., Brodhag, 1999; Block et al., 2013). Urban Agriculture has gained attractiveness because it responds to a range of urban issues that are often linked to the central goal of creating a sustainable city and the new sustainability goals (Mougeot, 2006; FAO, 2007; Mendes et al., 2008; Lovell, 2010; UN, 2016). Reynolds (2008) defines Urban Agriculture as a global movement aimed at engaging people in collectively designing, organizing, realizing and taking care of public farms and gardens in their own cities (Reynolds, 2008). Urban Agriculture is made up of a wide spectrum of temporal land use, ranging from permanent to short-term (Halloran and Magid, 2013). In general, these include community gardens (McKay, 2011), urban allotments (Crouch and Ward, 1997) and guerrilla gardening spots (Tracey, 2007). Growing can be done through a broad array of loosely-formalized or unstructured practices transforming neglected or void urban spaces into enjoyable, pulsating places (Hou, 2010). The potential of Urban Agriculture has been welcomed as a concrete and actioninducing strategy by many governments and institutions since it is relatively easy to establish. Urban Agriculture initiatives have therefore been discussed in many international contexts recently, but less so in a Swedish context (Larsson, 2009; Nilsson and Wiman, 2015). Prové et al. (2016) argue that there is a prevailing assumption among scholars that the actual development of Urban Agriculture projects and policies is of greater significance than the impact, objectives and precise form of such initiatives (Prové et al., 2016). The forms and organization of Urban Agriculture are highly context-dependent and that every city must have its own way of setting up Urban Agriculture initiatives (Ferris et al., 2001). Therefore, it is important to see each Urban Agriculture project as unique, as Urban Agriculture governance is dependent on city-specific circumstances (Prové et al., 2016).

\section{Community gardening, stakeholders and governmentality}

There are many stakeholders involved in Urban Agriculture, ranging from citizens to authorities and housing companies, as well as NGOs. Urban Agriculture can cause tensions between stakeholders' various perspectives, including how they view the gardens and how they interpret their meaning. In this study, we focus on community gardening, which is a distinct form of Urban Agriculture. Even though community gardening, household gardening and garden sharing are not market sources of local food, they provide the engaged households with local food access. To define what community gardens are, we use a definition by Glover (2003, p. 264) who says community gardens are 'organised initiative(s) whereby sections of land are used to produce food or flowers in an urban environment for the personal or collective benefit of their members who, by virtue of their participation, share certain resources such as space, tools and water' (Glover, 2003, p. 264). Community gardens are therefore areas of land gardened collectively by a group of people. The literature on community gardens tends to view 'community' as territorial and place-based, although there are also non-territorial food communities such as organized through social media. Successful community gardens have been shown to develop their own community through the nurturing of social capital in three key areas. These areas are: (a) bonding social capital through providing a place where different types of people meet, (b) bridging social capital through membership of networking organizations and (c) linking social capital via contact with other organizations (Firth et al., 2011).

Community gardening is discussed widely in the alternative food system literature. Seyfang and Smith (2007) suggest that these kinds of food projects are part of an increasing number of small-scale, bottom-up projects being led by community groups and individuals that collectively have the potential to engineer sustainable development. We look at community gardens through the lens of governmentality. ${ }^{1}$ Governance is important to the development of community gardens, because the way an urban area is governed can ultimately influence how land is managed and allocated, thereby affecting the tenure of these spaces. Urban green spaces, such as community gardens, are incredibly vulnerable to neoliberal development policies, such as commercial developments creating housing complexes and commercial centers, malls, etc. Community gardening has been portrayed as a part of the neoliberal strategy for gentrification processes, where community gardens are used to make areas more attractive, which then increases neighboring housing prices (Voicu and Been, 2008; Tornaghi, 2014). Similarly, it has also been portrayed as a means to outsource public space maintenance to volunteer citizens (Knigge, 2009; Rosol, 2012; Tornaghi, 2014). Geography and planning literature has described the neoliberal transformation of the city extensively, and this will not be dwelt upon here (Harvey, 1989; Schmelzkopf, 1995; Brenner and Theodore, 2002). However, originating from Lefebvre's work (2014), some scholars have interpreted the community gardening movement as a manifestation of the increasing power of alternative urban culture against the pervasiveness of neoliberal order (Purcell, 2002; Rosol, 2010; Whitehead, 2013). Rosol (2010) has said that new forms of governance-beyond-the-state have emerged, for instance, autonomously organized projects and active citizen participation. This has led to an

\footnotetext{
${ }^{1}$ We mean an additional horizontal approach to gain an understanding of underlying relationships, which constitute the people and institutions, where government is viewed not as a sole actor but, rather, as an assemblage of diverse elements, practices and ways of thinking that is coming together to both frame and resolve problems within a population.
} 
increasing importance of non-state actors. According to Rosol (2010), territorially defined local communities are relevant actors in urban governance. This development goes hand in hand with the rising importance of civic engagement (Rosol, 2010). Community gardening is also regarded as an opportunity for empowerment of citizens (Beck, 2001) and the alternative use of public spaces and is also understood as an expression of countercultural practices. Community gardens have been regarded by some as a form of the 'right to the city' culture (Purcell and Tyman, 2014; Prové et al., 2016; Certomà and Notteboom, 2017). They can also be regarded as a battle for existing commons (Seitz, 2011; Tornaghi, 2012; Colding and Barthel, 2013). Jessop (2002) suggest that they are part of a new political tenet that "tends to promote "community" (p. 108). This political strand of research has also been complemented by arguments that community gardening can be understood as an expression of citizens' willingness to give their voice to decisions on urban space planning (Prové et al., 2016; Certomà and Notteboom, 2017). Similarly, Tornaghi (2014) regards community gardening as a spontaneous and grassroots phenomenon that is anchored in urban counterculture and as a participatory tool to bridge the divide between policymakers and grassroots groups (Tornaghi, 2014). However, Certomà and Notteboom (2017) argue that the establishment of new community gardens has, in most cases, been facilitated through the city council or private actors as a form of governmentality (Certomà and Notteboom, 2017).

In many cases, city governments focus on single projects or experiments when implementing community gardening policies. Support for community gardens is given through trial and error, instigating lengthy learning processes on how to support and implement such initiatives, with decisions often only reached incrementally (Mintzberg et al., 1998; Teisman, 2000; Block et al., 2012). Explicit or clear-cut governance frameworks for community gardens currently remain absent, incoherent or unclear. In many cases, policy making marginalizes community gardens as food production without the consideration of other relevant policy domains that embrace different aspects of community gardens (Lovell, 2010).

Various researchers have shown that the benefits of taking part in a community garden are not limited to food production. Community gardens are also important for community-building (Milbourne, 2012), improving health through stimulating physical activity and consumption of fruits and vegetables (Wakefield et al., 2007), as well as providing green, open spaces that contribute to biodiversity (e.g. Miller, 2005; Colding and Barthel, 2013).

\section{Project methodology}

The community gardens that are studied in this paper were set up between 2009-2014 on municipal land in
Stockholm. We took this approach because we wanted to study projects that had been running for at least a couple of seasons, mainly because it is hard to predict the sturdiness of a newly started project and we wanted to draw on the experiences of established projects rather than learning about the process of setting up a new project. We use community gardening in Stockholm as a qualitative case study. In order to investigate the community gardens' sustainability and these new forms of citizen-led initiatives in Stockholm, an analysis of community gardening initiatives in Stockholm has been conducted. Stockholm provides an interesting case study for two reasons. First, Stockholm's community gardening initiatives are not well-represented in the international academic literature; second, Stockholm's urban structure is characterized by urban formal planning practices, and the informality of the development of community gardening is a contrast to this official planning policy. This is not unique, but this has led to a rather ad hoc and unplanned approach from the municipality to community gardening. In the following remainder of this section, we will give a general exploration of the development and character of community gardening in Stockholm and present the results of our case study.

Semi-structured interviews with key informants from the community gardens included in the study have been conducted both in groups varying from 5 to 12 people, conducted both on-site and in their community meetings as well as individually. The participants gave their consent to use their names in the text when they are cited. We have also undertaken participant observations at monthly meetings held at the 'Trädgård på spåret' (authors' translation: Garden on the Tracks) and 'Areal 127' during the winter season of 2015-2016. We participated in order to learn about the planning process of running a community garden and to understand the obstacles and the gardeners thought and intentions of running a community garden. Field notes were gathered at these meetings. Field visits to 15 gardens during the summer of 2015 and 2016 were also conducted in order to gain a better picture of the gardens' size, type of cultivation and the locality. We also posted an online survey in these gardens' facebook groups and 56 gardeners from different community gardens in Stockholm participated. In the survey, questions were asked about why they were involved in community gardening. These combined data sources have given a broad understanding of the experiences, attitudes and challenges the gardeners were facing. Furthermore, we conducted telephone and email interviews with municipality officers in all the 14 districts in Stockholm in 2014, 2015 and 2016, where questions were asked about their thoughts on the phenomena of community garden projects in their districts. To develop a deeper understanding of the problems that the community gardens were facing and how different municipalities around Sweden were handling and managing community gardens, we participated in and attended other meetings, conferences and 
garden shows in different parts of Sweden. Again, the reason for attending was to develop a deeper understanding of the community gardening scene in Sweden, and the challenges that community gardeners are facing. We have also conducted an in-depth interview with a community garden facilitator in the town of Malmö, a city in the south of Sweden. The aim of this was to learn more about the role of facilitators, and other strategies to sustain community gardens that could be used in Stockholm. It was also a way to discuss best practice for involving authorities in supporting gardening activities, thus improve the duration of the gardens. We have also followed the community gardens via their facebook groups to gain a deeper understanding of the community gardening activities and the challenges that community gardeners face with the day-to-day maintenance of the gardens.

All data were then thematically analyzed to give us: (1) an overall understanding of the varieties in practices and conditions that affect the organization of the gardens, and (2) more specifically the driving forces of the gardeners and other stakeholders to develop and maintain the gardens.

\section{Results and analysis}

\section{The community garden context in Stockholm: a case study}

There is little written about community gardening in Stockholm, however, Björklund (2010) has found that food production initiatives in and around Swedish cities are not new. Stockholm has a long history of public gardens, (e.g. wartime gardens and allotment gardens); however, community gardens are a recent form of urban food growing projects, and they are mainly a 21stcentury addition to the green space infrastructure in the city (L. Näslund, personal communication, January 21, 2016).

The city of Stockholm is characterized by densely populated areas, due to the lake Mälaren that restricts the growth of the inner city. The city takes up $187.16 \mathrm{~km}^{2}$ of land, of which $40 \%$ are parks and uninhabited green spaces. The citizens of Stockholm are close to their green spaces. More than $70 \%$ have park or nature within $200 \mathrm{~m}$ from their residence and $90 \%$ have it within $<300 \mathrm{~m}$ (Borg, et al., 2013). The need for more green areas is not what inspired Stockholm inhabitants to engage in community gardening per se, but rather the desire to grow local produce and to experience social relationships and place attachment, sense of togetherness and purposefulness, and to have the pleasure of caring for the city in unloved urban brownfields (Survey, 2016).

In recent years, the interest in Urban Agriculture, especially community gardening, has increased significantly in the city of Stockholm. Alongside the city's popular allotment areas, there are new places where the locals have, on their own initiative, become committed to cultivating gardens together - on housing estates, parks and natural areas, as well as on abandoned railway tracks (. . Stenmark, personal communication, March 28, 2017). As has been stated in the introduction, this paper explores the emergence community gardening initiatives in Stockholm and scrutinizes it by looking at the citizens' planning initiatives and the local administrations' attitudes towards community gardening. Of particular interest are the motives and outcomes of such initiatives. Community gardening, as stated above, is a relatively new concept in Stockholm. Other forms of Urban Agriculture, like rooftop gardening, aquaponics and vertical gardening are even more rare and only in their infancy. Today, community gardening does not contribute substantially to supply food to the city of Stockholm; this is similar to community gardening practices in other Northern European cities (Halloran and Magid, 2013).

According to one of the former board members of the garden association 'Trädgård på spåret,' the first contemporary collaborative community garden was established in Stockholm 7 years ago (K. Johansson, personal communication, November 2, 2015). Between 2010 and 2016 , interest in community gardening grew exponentially as a variety of community gardening projects were developed and implemented. Simultaneously, awareness among the general public was raised. It was expressed in blogs and facebook pages, and therefore the media coverage of community gardening projects grew. A variety of conferences and workshops were organized by different organizations with outspoken 'sustainable city agendas'. Most projects have occurred independently of one another, and there have been few, if any, attempts at coordinating these ventures. According to the founder of the garden association 'Areal 127,' community gardening in Stockholm has its roots in the renewed attention in urban green areas and guerrilla gardening by environmentalists (A. Bulukin, personal communication, December 3 , 2015). These initiatives from the guerrilla gardeners were intended as civic engagement that was able to attract public attention to the lack of available green areas and their degradation. Most of them were intended as symbolic gestures, mainly initiated by middle-class educated people or citizen's associations and contributed to the diffusion of gardening cultures and established contacts with relevant administrations (L. Näslund, member of Trädgård på spåret garden association, personal communication, January 21, 2016). In 2013, a network called 'Urban Farming Stockholm' started as a platform for different organizations engaged in community gardening in and around the city. The people behind this network were all leading figures in the community gardening movement in the city. Due to its infancy, there was no citywide vision for community gardening (A. Bulukin, personal communication, December 3, 2015; and L. Näslund, personal communication, January 21, 2016). Despite this, community gardening, although not 
explicitly mentioned, fits into a variety of current municipal visions such as the planning documents 'Den gröna Promenadstaden 2013' [title in English: The green walkable city 2013 - the Stockholm city plan]. Moreover, there are no previous laws designed to govern the practice.

\section{The arrangement of the community gardens}

The official stance among the municipal officers in Stockholm was that community gardening contributes to its beautiful, well-kept, vibrant and safe environment, while generating social cohesion in the surrounding area and that it affects the local environment in a positive way through further social interaction and presence in the common areas. They aimed for the city's community gardens to turn into exciting places where people from different cultures meet and share cultivation experiences (Borg et al., 2013).

At the time of the study, Stockholm had approximately 40 community gardens scattered throughout the city and its suburbs. When viewing the distribution of community gardening initiatives in Stockholm it is noticeable that a large number of initiatives are located in the southern and central districts. Many were present in the city center and in the more recently developed areas in the south-east and northern sides of Stockholm. These areas have a population of well-educated and environmentally conscious citizens (SCB, 2016). Notably, fewer community gardens were present in the districts north and north-west of Stockholm (Fig. 1).

The community gardens were usually very small in size $\left(10-30 \mathrm{~m}^{2}\right)$ and had between three and ten people actively involved. The number of community gardens had been rising every year, however, some were just there for a year and then are abandoned. The community gardens were all newly established and the growers tend to draw people from the middle class who were a trend- and environmentally-conscious. The community gardens considered in our research were all collective and public in character. By 'public,' we mean that there was public access to the gardens anytime, i.e., they were open to the public to enter and to look around, and even to sit down and relax in the garden. As public gardens, they fulfilled important functions, social or otherwise, that were relevant for a broader group of people or for the whole neighborhood. According to the gardeners, the community gardens in Stockholm should have had a productive function, i.e., vegetables should be grown, but flowers were also planted in some cases. Almost all planting was in raised beds in wooden boxes i.e., in a pallet (A. Bulukin, personal communication, December 3, 2015; and L. Näslund, personal communication, January 21, 2016) (Fig. 2).

According to the municipality officers, community gardens geographically located outside the central parts of the inner city in the south and north had another purpose. They were started as a way to help people to re-commit to the construction of daily space in areas where there are socio-spatial conflicts, and where gentrification processes were taking place. These initiatives were often supported by the housing companies, for example 'Stockholmshem', a state-owned housing company that mainly provided community housing (see Table 1). These initiatives were launched by environmentally conscious citizens living in this community housing, and the housing companies themselves who wanted to introduce local food to the area. However, our investigation shows that the commitment from larger group of citizens was rather low and that these projects were struggling to survive. Most of the more successful gardening projects emerged due to cooperation between informal gardening groups and the district administration. The administration supported grassroots public space planning, together with traditional planning agents (e.g. administration or building companies).

Some gardens had collective areas only, while others also had some beds managed by individuals. The community garden groups were organized in different ways, ranging from loose groups to formally registered associations. The groups received funding from various sources. The most common sources were member fees and member donations; however, some received donations from companies or funds, e.g. through sponsored pallets or soil. Most of them received public funding as well, mostly for the physical creation of the gardens, soil, pallets and space; rarely for maintenance costs. The gardens were all managed by the members in their spare time and no one was employed to do so.

\section{The municipality's incentive for providing land}

Stockholm is divided into 14 district administrations and each is responsible for the maintenance of city parks. It was at this level that decisions are made about community gardening. Community gardens in Stockholm fell under the remit of various governing bodies within the districts. In this respect, the traffic office and the district administrations planned where community gardens can be located together. At the time of publication, Stockholm is developing a new park plan and it will hopefully discuss community gardening and how the city administration can meet this new interest in cultivation. While waiting for a common plan, the various district administrations have chosen to resolve the issue of community gardening in different ways.

When the first garden, called Trädgård på spåret (in English: Garden on the Track), started in 2012, they learned that the Stockholm administration's approach towards setting up a community garden was that it should be a bottom-up, grassroots-inspired process, i.e., they had to make the arrangements for the gardens themselves (L., Näslund, personal communication, December $2,2015)$. This was acknowledged in our conversations with the administrators (district administration officers 


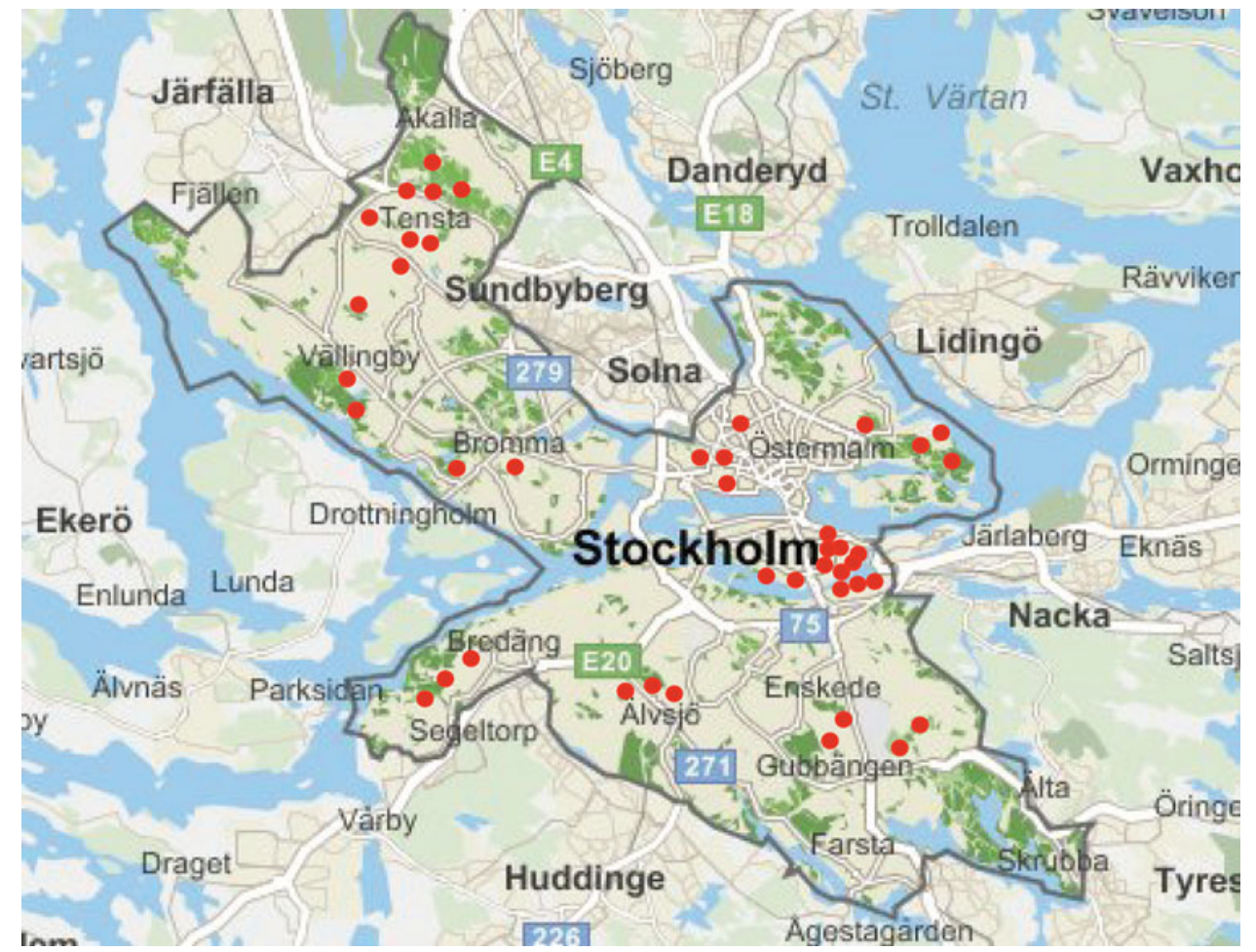

Fig. 1. Map of community gardens in Stockholm. Source: own survey.

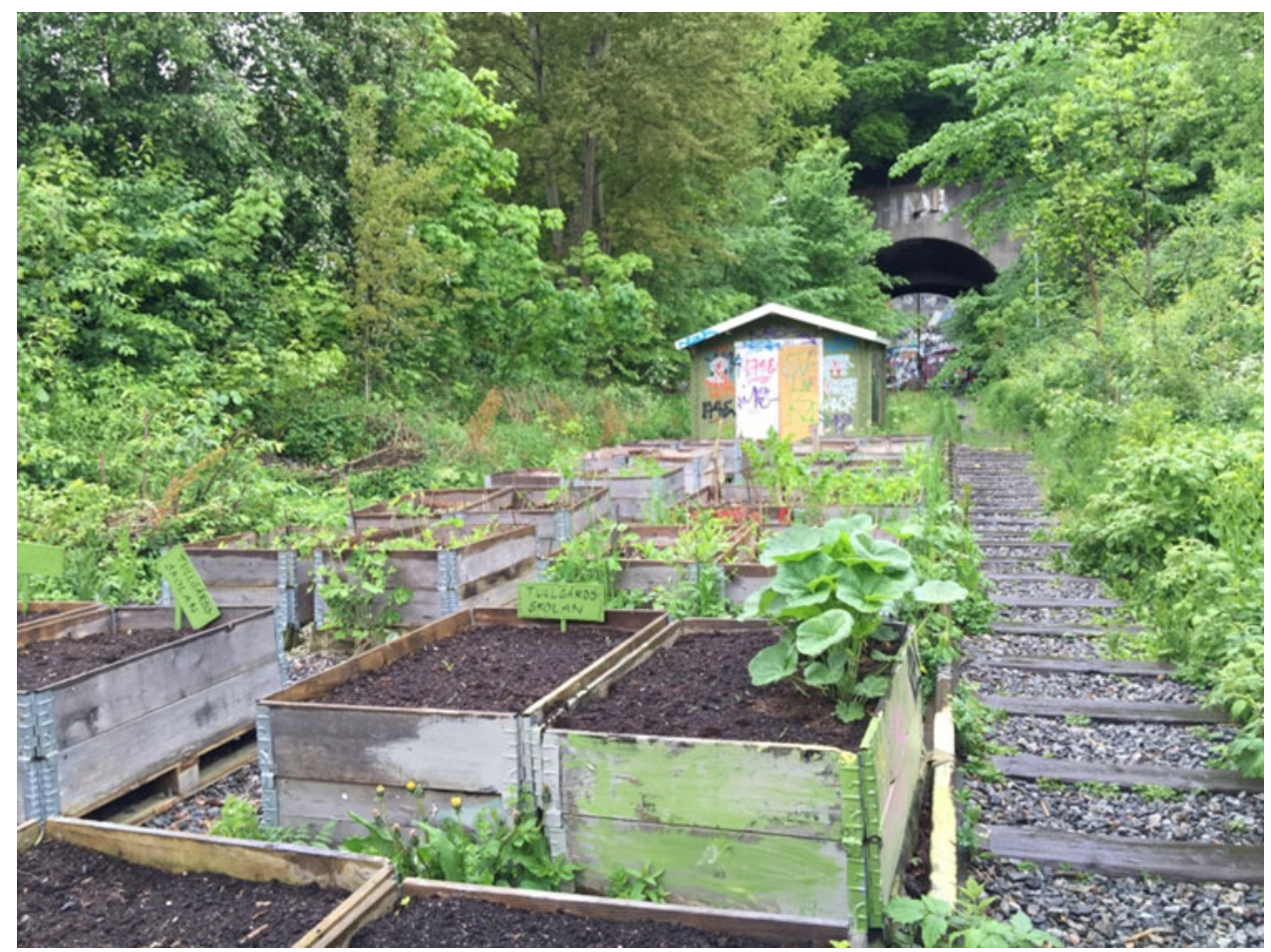

Fig. 2. Raised beds in pallets at Trädgård på spåret (Garden on the Track).

in Skärholmen,Skarpnäck, personal communication, April and May, 2014 and April 2016). Furthermore, as explained by district administration officers in Skarpnäck, Skärholmen and Norrmalm on how many gardens there will be, depended very much on the reaction of the Stockholmers to community gardening and the demand they generated for more urban space to be dedicated towards the projects (district administration officers 
Table 1. Reasons why the city administrations are engaged and supporting community gardens.

Answers form the suburban district administrations

Easy to remove if it gets bad results/pallets and raised beds are movable

Improves public health

Meeting place for citizens

Neighborhood watch

Increases safety in residential areas

A supplement in poor parks and nature areas

Facilitates exchanges of cultural traditions and knowledge

Creates community

Facilitates integration

Stimulates outdoor activities
Answers form the inner-city district administrations

Easy to remove if it gets bad results/ pallets and raised beds are movable

Provides more opportunity to grow

One way to restore parks

Creates commitment to the city and green areas

Increases the beauty of the city

Climate benefits

Preserves the city's green areas, a form of sustainable urbanization Reduced transport of food to increase sustainability

Promotes biodiversity

Source: Interviews with city planners in the district administrations.

in Skarpnäck, Skärholmen and Norrmalm, personal communication, April and May, 2014 and April 2016).

The City of Stockholm has provided support for projects, through a 'demand driven' approach to community gardening, mainly in the form of leasing land to the community gardening projects (personal communication with municipality officer at Norrmalm May 2, 2014). Without this support, it is doubtful that many community gardenrelated projects would be in existence today due to the high cost of land leasing. For most of the community gardens, the Stockholm municipality was the landowner and it appeared that the city functioned merely as the landowner rather than acting as an actual governing body. The majority of the community garden associations had a so-called 'user's agreement'. This user's agreement clarified the responsibilities of the involved parties (community garden and municipality). This included the length of the lease, what should be grown and who was responsible for the water supply. The agreement may have been terminated by either party if desired. Most of the community gardens had yearly lease agreements and this was something that is important for the district administrations, because then they could be terminated at any time for new economic development projects. In the beginning, every district administration had its own way of setting up community gardens but since 2015, most of the district administrations had a list with four steps posted on their web page for those who wanted to start a community garden project. Below is an excerpt from of what one of these looks like (authors' translation from Swedish into English):

1. 'Propose and plot your location on a map and contact your district administration to receive advance notice if the site is available for gardening.

2. Gather a few people who are interested in community gardening and form an association.

3. Make a description of how many pallets or square metres you need for cultivation. Draw on a map the location where you wish to cultivate, and make a list of members and contacts in the group. Describe what you plan to plant.

4. E-mail the information to the district administration and sign a user agreement for your community garden' (Stockholm City, 2016a, b, accessed 2016)

This kind of information was not available when the first community garden was established. At that time there were no formal contracts to sign and the administration was unsure how to handle the requests for creating gardens, which meant that the gardeners had to invent ways to get around the bureaucracy (L., Näslund, personal communication November 2, 2015, January 21, 2016). The absence of guidance led to vague responsibilities and leadership, and unclear expectations of the outcome of the gardens (A., Bulukin, personal communication, December 3, 2015).

In 2013, an official document called 'The green walkable city' (authors' translation) (Borg et al., 2013) was published, as an addition to the Stockholm City Plan. It expressed support for various forms of Urban Agriculture, in particular, community gardening. The Stockholm municipality's planning strategy concludes that community gardening is something that should be prioritized and the official stance is that the city will work to improve the residents' ability to influence their environment by, for example, gardening in various forms (Borg et al., 2013, p. 19).

In 'The green walkable city' document there were a number of strategies to manage parks and the green areas in Stockholm. One of these strategies was called 'Engaged and involved locals' (authors' translation). This strategy's aim was to improve citizens' abilities to influence their neighborhood area and give them a chance to take part in community gardening. Likewise, the city mentioned that community gardening is good because it creates meeting places and builds safe and attractive neighborhoods, which are considered important, especially in socially deprived areas. According to this strategy, the city will actively support projects such as community gardens. 
When community gardens were first being established (2012-2015), the municipality officers only acted on direct requests from individuals or associations attempting to set up community gardens; the municipality officers did not construct community gardens themselves. In this initial phase, the district administrations were not actively looking for interested growers; the idea needed to come from those citizens who actually wanted to grow. The municipal officers felt that if it were a bottom-up initiative, it would increase the chances of having successful long-term community gardens as the commitment from the gardeners would be higher (district administration officers, in Skarpnäck, Skärholmen personal communication, April and May, 2014). To some extent, this view has changed, and for the 2016 growing season, one inner-city administration in Kungsholmen created community gardens first and then placed ads in the local newspaper and on websites to attract growers. The project was terminated after one season and at the time of publication, is planned to be evaluated to see whether the projects were successful (Brandt, 2016).

Most district administrations encouraged residents to engage in community gardening. They stated that anyone who wanted to grow could apply for permission to grow on the city's land. If the permit was granted, the district administration usually offered a starter kit consisting of a pallet filled with organic soil (Stockholm City, 2017). The reasons for supporting community gardening projects were different for the inner city and suburban city district officers (Table 1). Most district officers state that community gardens were easy to remove if the gardeners stopped coming, but the suburban district administrations' officers also stated that it was good for the citizens since gardening can improve public health. Community gardens can also create new meeting places for citizens and gardens can have neighborhood watch functions and increase safety in residential areas. The inner city administrations saw community gardens as one way to restore parks; they help to create a commitment to the city and green areas, as well as increase the beauty of the city. According to the district administration officers, community gardens also have climate benefits and provide a more sustainable urban environment (see Table 1).

Most of the district administration officers stated that the opportunity to join a community garden association is perfect for anyone who lives in an apartment and does not have an allotment but would like to grow. The district officer in Skarpnäck I Bogne stated that 'in this way, larger groups get the opportunity to grow on municipal land' (I., Bogne, personal communication, April 24, 2016).

\section{The growers' incentives for participating in community gardening}

A common denominator for all respondents in the community gardens was that they expressed gardening as a strategy to contribute to sustainable development. They see gardening in the city as a key to reducing the distance food travels from the field to the table and allowing for more efficient use of energy and natural resources.

\section{'Trädgård på spåret'}

In 2012, Trädgård på spåret, a portable vegetable garden in wooden boxes located on a railway track, was started. It was placed on an abandoned railway track area beneath Skanstull in Södermalm, Stockholm; the place became a community garden with four manifestations: an organic farming school, a green market, an urban garden and an organic café (Fig. 3).

The promoters of the programme were Philipp Olsmeyer, Max Zinnecker and Lisa Kopp. The start of Trädgård på spåret played a fundamental role in the development of the community gardening movement in Stockholm, advancing a dialogue with local administration by inviting traditional stakeholders (institutional planners, private land owners and companies) to take part in the garden planning process.

'We thought it was a nice but poorly utilised place where something should be done' (P., Olsmeyer, personal communication, November 2, 2015). The idea of a garden came from Prinzessinnengarten in Kreuzberg in Berlin, where, in 2009 , a space was converted from a 60 -yearold vacant lot into a compound-led mobile urban farm for all, with a focus on learning. The second model was the High Line in Manhattan, New York, which is a green ecological trail that connected neighborhoods (K., Johansson, personal communication, November 2, 2015). The founders had no particular gardening skills in the beginning, which meant that everything was done through trial and error, resulting in a low-harvest yield.

One of the programme promoters said, 'We believe that there is great interest and need for knowledge about growing vegetables among the people of Stockholm.' In the first year about 70 people signed up for memberships and many signed up as sponsors. Both businesses and individuals could be sponsors by paying 1000 Swedish Kronor (SEK) (approximately 100 Euros or Dollars) for a pallet with their name on it, which would be managed by the community garden members (K., Johansson, P., Olsmeyer, personal communication, December 2, 2015).

The name 'Trädgård på spåret' has several meanings. First, the garden is placed on a railway track, however, it also shows that it is a mobile garden that can be relocated - it does not need to be in Skanstull forever. In addition, it means that the garden is on the 'right track' in terms of sustainability.

Even though Stockholmers regard themselves as relatively environmentally conscious, one of the programme promoter's opinion was that Stockholm was a little behind other cities and thinks that it was because there was not as much local urban initiative here as there has been in Berlin, saying 'town life here has been so good 


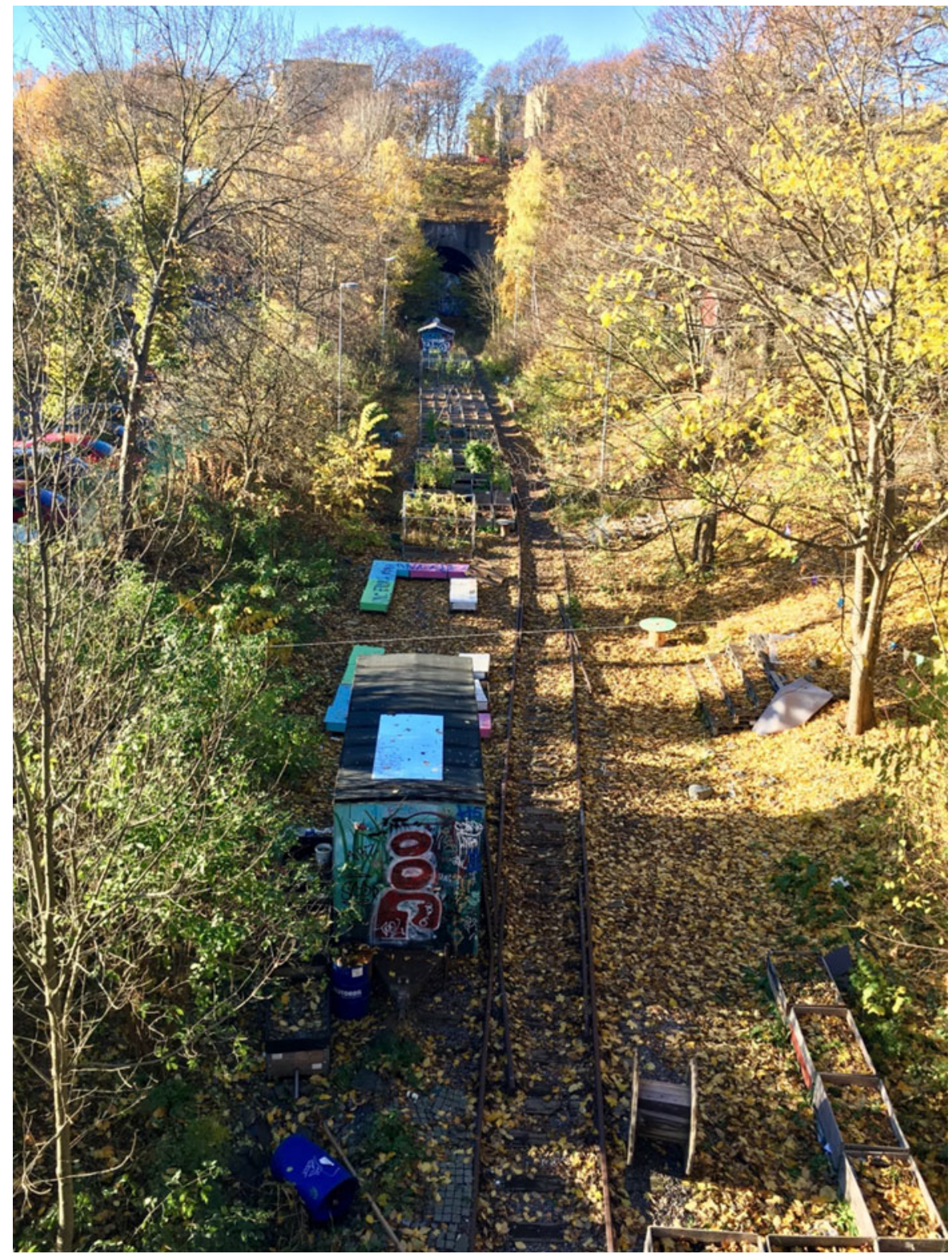

Fig. 3. Trädgård på spåret with a coffee shop in the foreground and pallets for cultivation further down. Source: Maria Normark 2015.

they often expect someone else to take the initiative' (P., Olsmeyer, personal communication, November 2, 2015). He thought there is a longing to be able to grow in the city. However, there had not been a lack of green areas or food in Sweden; the longing was because gardening is fun and people could learn something. He said that the normal way city planning took place in Stockholm was that an architectural competition was announced, and afterwards when it was completed, disgruntled citizens complain about the outcome. He believed it was better if they were engaged in the plan before, or even took the first step. The association Trädgård på spåret has been invited by the development office and city planning to participate in the south city planning process that will transform the area where the track is located at the time of the study (L. Näslund and P. Olsmeyer, personal communication, January 12, 2016).

\section{Community garden associations 'Folkodlarna', 'Bagisodlarna' and 'Areal 127'}

The association Folkodlarna in Skarpnäck (in English, authors' translation: Growing Folks in Skarpnäck, an area of Stockholm) had sustainable development as their main focus when they created the association, but they were also concerned about food deserts in the city and the long distance food travels from the farm to plate. Their vision was to be able to grow some of their own food with others. The association pointed out that 'it is not only about securing resources for us, but also 
about creating a just and sustainable world... We grow not only vegetables, but also a community, security and a beautiful local environment. It's the beginning of something new' (Folkodlarna, 2016, authors' translation from Swedish to English).

The reasons for starting the project with Bagisodlarna (authors' translation from Swedish to English: Bagis' farmers, Bagis is a nickname for the Bagarmossen district) can also be traced to both ecological and social sustainability. According to a personal communication with the person responsible for the housing estate company that owns the land, Stockholms Hem, the main reason was to develop a green space as compensation for another that was lost ( $\AA$. Stenmark, personal communication, March 28, 2017). In this case, the local housing company was involved. The cultivation of the areas of Hökarängen and Bredäng started because the residents wanted to devote themselves to farming as a social activity in the context of reducing their carbon footprint, which also, according to them, made the cultivation both socially and ecologically sustainable. The residents considered it to be socially sustainable since it could be seen as a participatory project and a meeting place open to all. It was important that it was socially sustainable, but also that it promoted well-being $(\AA$, Stenmark, personal communication March 28, 2017).

In our survey using multiple choice questions directed towards the growers, another picture emerged. Almost all of the gardeners answered that they were engaged in a community garden because it was fun (48 persons). The second most frequently reported reason was to promote the environment and biodiversity (33 persons); then the psychological and mental health aspects were also mentioned as a very important factor (29 persons). Other reasons for engagement were that they felt at ease in the garden and that it was meditative and soothing. A common answer as to why the gardeners were engaged in community gardening was that they did it to meet other people, i.e., the social aspect was very important; more than improving the environment or the produce (see Table 2).

\section{Temporality and permanence of community gardens}

The following section will interpret the results by analyzing the temporality and permanence of the community gardens. The community garden initiatives in Stockholm demonstrated varying levels of temporality. Trädgård på spåret's community garden association was created with the understanding that they would have to be relatively mobile, as they exist in an area where new city development is planned. The area will be built upon in the near future. 'We rent this area annually from the City of Stockholm; they do not know when, but we guess that it will be at least three years before we have to move. We take it season by season', said L, Näslund (personal communication, January 12, 2016). This came more quickly
Table 2. Why the gardeners are engaged in community gardening.

Fun/enjoyment

Mental health aspects: e.g., meditative space, soothing

To promote the environment and biodiversity

Traceability: to know the origin of the vegetables

Socially: to get together with others and make new social contacts

Physical health issues: working with the body

Source: Survey and interviews with gardeners.

than expected and in the spring of 2017 the garden was terminated (Trädgård på spåret, 2017). Folkodlarna in Skarpnäck also ended their association in the autumn of 2016 and returned the land to the municipality (Folkodlarna, 2016). More permanent activities could sometimes be viewed as a threat, or a misuse of space by the municipality and other citizens, since land is expensive and longer leases would make it hard for the landowner to evict community gardens if that land were to be developed into something else, such as apartments (L. Näslund, personal communication January 12, 2016).

Five years ago the local government officials saw community gardens as something that must be used by groups and associations and other land use was viewed sceptically, from the point of view that 'we don't want this to develop into privatisation on public land' (I. Bonge, personal communication, April 26, 2016). But at the time of this study, this seemed to be changing and more and more community gardens had private plots as well, although the user contracts were still only 1 year long.

The temporality of the garden user contracts was a problem since growing crops takes time and one growing season is nothing in terms of time that it takes for a garden to develop. This was also expressed by the project manager, Alsterhed, of the association 'Jordliga broar' (Bridges of soil, authors' translation from Swedish to English). Alsterhed thought that the lack of understanding of how much engagement and time was required in order to get a good community garden running was hampering the projects. 'Community gardens need time to get up and running. At least 5-6 years is needed and short-term leases are not helping' (C. Alsterhed, personal communication, April 15, 2014). It is obvious that the level of spatial permanence or temporality reflected the impermanent nature of community gardens in Stockholm. Consequently, shorter-term crops like leafy green vegetables were generally grown but trees were not, although they would sometimes be better suited to the urban environment.

The community gardeners of the garden Areal 127 have been subject to the issue of temporality. When the district administrations suddenly decided to build a public toilet at the community garden's location, the garden had to close during the construction period. A miscommunication resulted in a situation where the city administration started the demolition of the garden before the growers had time to 
move the pallets. The gardening had to be put on hold, but after hard and dedicated work from the president of the Areal 127 association, the district administration restored the park, built new pallets and provided a water tap. Unfortunately, it was late in the growing season and many of the members had already left the community garden association, and therefore the season of 2016 was wasted (A. Bulukin, social media communication, 2016).

Temporality was also evident in the district of Kungsholmen. As mentioned above, the district administration started four community gardens themselves in the season of 2016. The project lasted for one growing season and the pallets were taken away. The district administration evaluated the initiative during the winter 2016/2017 to see if the projects were successful or not (Brandt, 2016). However, according to personal communications with A. Bulukin (2016) and C. Alsterhed (2014), one season was not sufficient for evaluating a growing project. It takes time to establish these kinds of projects.

\section{Facilitator incentives}

One shared problem in the community gardens we have been studying is that they relyed on one or two people to coordinate the whole association. Often it was the founder (s) of the associations who end up with a heavy burden on their shoulders. They were the ones who made everything move forward and taking the initiative to meet. They often ended up with the responsibility of watering the plants during periods of the summer when everybody else was away, and they were the ones who kept in contact with the district administration and informed new members and the general public of the garden. They also often had to manage social media, a web page and facebook, etc. In the beginning, this was often done with enthusiasm, but it became a heavy burden and they rarely had any time to grow themselves. Eventually, these people found they were no longer coping with all of the duties and they quit, meaning the fate of the garden was then rather uncertain. Sometimes another person stepped in, but we have learned that when a garden association is left without its driving force, it often ceases to exist. This is, of course, not a good way to handle the gardens if they are supposed to be part of a sustainable city.

Other cities in Sweden have worked with community gardening in another way. In the town of Malmö (the third largest city in Sweden), e.g., there was a facilitator who was a formally appointed, knowledgeable garden coordinator that worked with the various stakeholders, including the gardeners, municipality and housing companies. We interviewed an employed facilitator who coordinated several community gardens in the city. He was connected to an NGO that ran on various project funds (from housing companies and the municipality, as well as other smaller grants from other foundations and even EU funds). The head facilitator had years of experience in farming outside the city but he believed in the positive effects of community gardening and its ability to transform communities. He was active in several different community gardening initiatives and was also hired as a facilitator for community gardening projects in several parts of the city. He made sure that the projects were managed properly, and employed gardeners to assist the other community gardeners with maintenance, crop advice, tidying the gardens, etc. He guided us through the community gardens where he worked, and in an interview, he shared his experiences of being active in non-profit organizations and collaborating with the municipality and housing companies to start and maintain community gardens. He acknowledged and regretted the lack of support and management from the municipalities, both financial and social, to make community gardening initiatives function on a long-term basis. He described their roles as facilitators and upholders of community gardens as a kind of employed version of enthusiasts that keeps other farms going. Their approach to embarking in a community garden as facilitators were described like this:

'We don't do this kind of mushy-mushy fuss [for the residents], instead we have consciously worked foremost at 'Herrgården' with just starting the cultivation in the beds and then people can come voluntarily and help and take part and adopt a bed and we call it "social ecological farming at Herrgården" (G. Larsson, personal communication, August 23, 2016).

The economic costs did not have to be that large, but there was a need to have a facilitator and that obviously came with some costs: '[The housing company] and us, we have the same common strategy too, and that is their gain in all this, to reduce maintenance costs and have people that take responsibility for their outdoor environment where they live, and this is exactly what is happening here' (G. Larsson, personal communication, August 23, 2016). The facilitators, therefore, saw a clear benefit from community gardening projects as a social project in neighborhoods. Larsson continued by saying:

'The best way of working with this is sort of non-profit forms of association, because there you avoid VAT (valueadded tax) and then/also you can apply for a lot more (...) different kinds of project funds. Non-profit associations have no limits in applying for project funds, but as a company you often get rejected' (G. Larsson, personal communication, August 23, 2016).

As we have seen in several of the community gardens in Stockholm, there was a need for organization and overview by someone who was involved with continuous maintenance, therefore there was a need to have a facilitator to help the community gardens function on a long-term basis.

\section{Discussion: Driving forces for participation in relation to the practical circumstances}

The community gardens in Stockholm were all in their infancy and their long-term future was hard to predict, 
but one finding of our study is that sustainability was hard to maintain among the growers themselves. Many city inhabitants were from a rural society several generations ago, which means they had no prior knowledge of growing and did not know what it takes to grow, store and make use of the produce. They started off very enthusiastically in the spring with the cultivation of seedlings and then planting in the beginning of the summer. Summer came and since they lived in the city they wanted to spend their holiday somewhere else. Swedes typically have 5 weeks of holiday and usually all of it is spent during the summer outside of the inner city in summerhouses or locations abroad (L. Näslund, personal communication, January 12, 2016). The problem then arises as to who will water the plants? 'Do they need watering every day?' (E. Bergendahl, personal communication, December 3, 2015). The fact that a raised bed in wooden boxes dries out quickly came as a surprise to many inexperienced growers (L. Näslund, personal communication, January 12, 2016).

The growers also started off by planting crops that are easy to grow, like carrots and leafy vegetables, and then it was hard to store and make use of all the vegetables that suddenly appear in larger quantities in the garden. The understanding of the process that inexperienced gardeners had was that you plant and then you just harvest. No work is done in between, or afterward. Many stop coming when they realize this (K. Johansson, personal communication, November 2, 2015; E. Bergendahl, December 3, 2015). All of the community gardens we visited had issues with watering (which was aggravated by the raised beds that dry faster than beds dug directly into the soil). They had watering schemes but almost all of them ended up with one or two people watering all summer by themselves. Another issue was the access to water. During the planning process, this was something that was forgotten. Easy access to water is essential for a garden, but hoses and keys to the taps were hard to come by because they were privately owned, or located far away.

The next issue was who may harvest and eat the vegetables. In a community garden, everything is usually communal, including the produce. But if half of the group does not participate in the hard work during summer but just shows up at harvest, should they have the same amount of produce as the rest of the group? Since the gardens often produced tomatoes and salad the question was, how many tomatoes could you eat if you have a small household? This part of the gardening activities was rarely planned for. The driving forces were the joy of gardening and enthusiasm for a cooperative project, but our conclusion from following these projects is that the more goal-oriented the community garden is in regard to planning the right kind of crops and having harvest throughout the season, the better chance the community garden has of lasting or at least keeping the gardeners active in the association.
The importance of the role of the facilitator

All of the community gardens we studied have had the same problem: the community gardens were managed by the association members in their free time and they relied on one or two people who coordinated everything from seeds to harvest. These people took care of the association and pushed the work forward in the community garden. In many cases, this person was often the one who was particularly driven and often the founder of the association who had a vision that goes beyond gardening as stated above. But facilitating is a task that takes a lot of time and effort, and when this person no longer had that time or will to continue, the community gardens had a hard time surviving, like Trädgård på spåret and Folkodlarna in Skarpnäck. Some of the unpaid facilitators had hardly any time to grow anything themselves since they were constantly needed to explain to inexperienced growers how to grow, to water the plants and also to communicate with municipality officers, raise money, educate and enlighten the wider community, local schools and kindergartens in his or her spare time. This was, of course, not sustainable for the facilitator or the association and community garden. This made the community gardens extremely vulnerable. How can these groups be supported? Could the municipality provide a paid facilitator instead of handing out soil and pallets? As the example from Malmö shows, a facilitator (a garden coordinator) might enhance the longevity of the community gardens.

This might be a typical Swedish problem because there is a different 'volunteering culture' in Sweden. The general pattern of volunteering is characterized by a focus on membership and 'voluntary activities' are, to a great deal, performed within the framework of an organization (Lundström and Svedberg, 2003). We argue that since the traditional forms of volunteering are rare we need to have other arrangements to run the community gardens.

As we have discussed regarding the most recent development, municipalities, housing companies and other organizations want people to start small-scale community gardens in their neighborhoods. The conclusion we can draw from these initiatives that we have studied is that bottom-up and top-down initiatives need to have a formalized role for a person responsible for facilitating and coordinating resources, planning, knowledge, etc. These projects are most likely to fail when there is no organization surrounding the community gardens. If this is to be a serious practice that lasts longer than one or two seasons, there must be some organization behind it. Simply providing citizens some bags of soil and some seeds result in slim chances of long-term success.

\section{Conclusions and future possibilities}

It has been argued that community gardening holds promise for sustainable lifestyles with its association 
towards ecology, food awareness and social sustainability (Milbourne, 2012). The main findings of this paper are that the district administration officers in Stockholm do, to some extent, share this view, but the cases from Stockholm do not support this argument. The projects that we have studied show that the community gardens are only marginally sustainable regarding food production or in their own survival. To make them more sustainable, community garden associations require knowledge, resources and clear goals to have the potential to become a more long-term phenomenon in the urban landscape. The current discourse in Stockholm regarding community gardening is that it is good for the city to be green and that community gardening is a strategy to deliver the vision of the sustainable city. We argue that there is a need to move beyond this discourse. The municipality officers have fallen for a societal narrative on community gardening that is both uncritically positive as well as decontextualized, as 'food, city planning, and public health must be discussed in tandem '(McClintock, 2014). The community gardening development in Stockholm is, as we have described, hampered by vague responsibilities and leadership, and unclear expectations of the outcome. The cases in Stockholm exemplify how formal and informal advocacy groups are collaborating, but that they often have different agendas and motivations for setting up new community gardens. The gardeners want to have a nice spot to socialize at and 'get their hands dirty', and if they get some produce that is a bonus. The municipality officers want it to be a part of the greening of the city and as a part of the city's plan to be one of the greenest and most sustainable cities in the world. They also see it as a part of social sustainability, believing that it would create community and act as a form of neighborhood watch. They also believe that it would increase safety in residential areas, and facilitate exchanges about cultural traditions and knowledge, and therefore facilitate integration. We see that the larger society (the municipality of Stockholm and the district administrations) have begun to embrace the concept of community gardening, and has therefore responded to citizens' requests for land and been willing to let it be part of the city landscape, but they are not really sure how best to execute and facilitate the gardens. The founders of the different garden associations we have met see social and ecological sustainability as a fundamental feature of their approach to community gardening in Stockholm even if they do not really produce much food. They also see the community gardens as a meeting place and an important place for social interaction and socializing with friends. We can see that community gardening in Stockholm is still in its infancy. However, to be able to grow and fulfill the dreams and visions of the community gardeners and city planners we argue that we can see an uncritical enthusiasm that results in an overly ad hoc approach to governance of community gardens and that the long-term viability of the community gardens is forgotten. One way of ensuring that this ad hoc short-term viability does not happen is by employing facilitators. We argued that if the community garden associations had someone to facilitate the groups, a person who could handle contacts with the municipality, inform new members, keep in contact with other associations and raise money, etc., it would give the group a stability that is hard to get if all the responsibility rests on a few enthusiasts. It is necessary, we argue, that funds and long-term engagement are tied to these kinds of initiatives. Relying on enthusiasm for gardening as the driving force for developing community gardens more permanently within municipalities is not, as we have tried to show in this paper, a lasting way of investing in urban green areas.

For some of the community gardeners, the vision for the future is that community gardening might evolve into a more widespread phenomenon than it is today. They hope that community gardening will be part of the infrastructure when new areas are planned. However, we argue that in its current form, it cannot be a viable way to ensure a food supply for the city. This is because:

- lack of knowledge is currently a challenge: growing vegetables, especially on a larger scale requires a substantial amount of know-how and experience on how to sow, harvest, store and use the produce to be successful

- the crops demands continuous attention: participating in a community garden not close to home requires commitment, maintain a watering scheme in the summer is a typical challenge, the commitments from the gardeners fluctuate during the season

- it is almost a negligible amount of vegetables that is produced in these small wooden boxes that are typically used

Currently, community gardening in Stockholm does not show real promise to contribute in any substantial way to an urban sustainable food system. There are, however, a few possibilities that may change this in a positive direction:

- municipalities and housing companies should also focus on knowledge support, as well as providing some physical prerequisites for growing (access to water, etc.)

- the gardens should be allowed to grow and become larger: the raised wooden boxes are convenient for quick and easy construction of the garden, but provide limitations, both in space and that they require more watering

- the land lease should be long-term: the yearly contracts the municipality offers restrains the stability of the gardens

- there is a need for investigating the organizations of the community gardens further: in the Swedish context, relying solely on a voluntary commitment by the gardeners is a challenge. Finding alternative organization forms, e.g., by hiring coaches, providing internships 
for students and long-term farming volunteers may provide further stability to the gardens.

Acknowledgment. We would like to thank the anonymous referees for their useful suggestion's and the Editors of this special issue. This research was supported by Östersjöstiftelsen (The Foundation for Baltic and East European Studies, Sweden).

\section{References}

Beck, F.D. 2001. Introduction to the special section, struggles in building community. Sociological Inquiry 71(4); 455-458.

Björklund, A. 2010. Historical urban agriculture: food production and access to land in Swedish towns before 1900, Doctoral dissertation. Acta Universitatis Stockholmiensis Stockholm studies in human geography NO 20, Stockholm.

Block, T., Steyvers, S., Oosterlynck, S., Reynaert, H., and De Rynck, F. 2012. When strategic plans fail to lead. A complexity-acknowledging perspective on decision-making in urban projects. The case of Kortrijk. European Planning Studies 20:981-997.

Block, T., Van Assche, J., and Goeminne, G. 2013. Unravelling urban sustainability. The Flemish City Monitor acknowledges complexity. In Ecological informatics, special issue on 'Unravelling Complexity and Supporting sustainability', pp. 104-110.

Borg, K.E., Hammarberg, U., Elfström, B., and Sabel, M. 2013. Den gröna promenadstaden: (The green walkable city) En strategi för utveckling av Stockholms parker och natur. Stockholms stad, Stadsbyggnadskontoret.

Brandt, P. 2016. Här kommer vem som hels att få odla (Online). Available at http://www.stockholmdirekt.se/nyheter/harkommer-vem-som-helst-att-fa-odla-fyra-nya-platser-pa-kungsholmen/aRKpdl!mvf8rPbJbjqEIQsuN9p1DA/ Published 13 April 2016 (Accessed 7 May 2016).

Brenner, N. and Theodore, N. 2002. Cities and the geographies of 'actually existing neoliberalism'. Antipode 34(3):349-379.

Brodhag, C. 1999. From rationality to governance: the decision process of sustainable development. International Journal of Sustainable Development 2(3):388-396.

Bulkeley, H. and Castán Broto, V. 2013. Government by experiment? Global cities and the governing of climate change. Transactions of the Institute of British Geographers 38(3), 361-375.

Certomá, C. and Notteboom, B. 2017. Informal planning in a transactive governmentality. Re-reading planning practices through Ghent's community gardens. Planning Theory 16(1): 51-73.

Coldinga, J. and Barthel, S. 2013. The potential of 'Urban Green Commons' in the resilience building of cities. Ecological Economics 86:156-166.

Crouch, D. and Ward, C. 1997. The Allotment: Its Landscape and Culture. Nottingham: Five Leaves.

Evans, N., Morris, C., and Winter, M. 2002. Conceptualizing agriculture: a critique of post-productivism as the new orthodoxy. Progress in Human Geography 26(3):313-332.

FAO 2007. Urban agriculture for sustainable poverty alleviation and food security (online). Available at http://www.fao.org/ fileadmin/templates/FCIT/PDF/UPA-WBpaper-Final October 2008.pdf (Accessed 10 October 2015).
Ferris, J., Norman, C., and Sempik, J. 2001. People, land and sustainability: community gardens and the social dimension of sustainable development. Social Policy and Administration 35(5):559-568.

Firth, C., Maye, D., and Pearson, D. 2011. Developing "community" in community gardens. Local Environment 16(6): $555-568$.

Folkodlarna 2016. Folkodlarna (online). Available at http://www. folkodlarna.se/facebook.com/folkodlarna (Accessed 10 March 2016).

Glover, T.D. 2003. Community garden movement. In K. Christensen and D. Levinson (eds). Encyclopedia of Community: From the Village to the Virtua World, vol. 1. Thousand Oaks, CA: Sage Publications. pp. 264-266.

Hajer, M.A. and Wagenaar, H. 2003. Introduction. In Hajer, M.A. and Wagenaar, H. (eds). Deliberative Policy Analysis: Understanding Governance in the Network Society. Cambridge, UK: Cambridge University Press, pp. $1-30$.

Halloran, A. and Magid, J. 2013. The role of local government in promoting sustainable urban agriculture in Dar es Salaam and Copenhagen. Geografisk Tidsskrift Danish Journal of Geography 113(2):121-132.

Harvey, D. 1989. From managerialism to entrepreneurialism: the transformation of urban governance in late capitalism. Geografiska Annaler: Series B 71(1):3-17.

Hou, J. 2010. Insurgent Public Space: Guerrilla Urbanism and the Remaking of Contemporary Cities. New York: Taylor and Francis.

Jessop, B. 2002. Liberalism, neoliberalism, and urban governance: a state-theoretical perspective. In N. Brenner and Theodore, N. (eds). Spaces of Neoliberalism: Urban Restructuring in Western Europe and North America. Oxford: Blackwell, pp. 105-125.

Knigge, L. 2009. Intersections between public and private: community gardens, community service and geographies of care in the US City of Buffalo, NY. Geographica Helvetica, 64(1): $55-52$.

Larsson, M. 2009. Stadsdelsträdgård - plats för gemenskap och kreativa processer. PhD Dissertation. Alnarp: Acta Universitatis agriculturae Sueciae.

Lefebvre, H. 2014. Dissolving city, planetary metamorphosis'. Environment and Planning D: Society and Space 32(2): 203-205.

Lovell, S.T. 2010. Multifunctional urban agriculture for sustainable land use planning in the United States. Sustainability 2(8): 2499-2522.

Lundström, T. and Svedberg, L. 2003. The voluntary sector in a social democratic welfare state - the case of Sweden. Journal of Social Policy 32(2):217-238.

McClintock, N. 2014. Radical, reformist, and garden-variety neoliberal: coming to terms with urban agriculture's contradictions. Local Environment 19(2):147-171.

McCormick, K., Anderberg, S., Coenen, L., and Neij, L. 2013. Advancing sustainable urban transformation. Journal of Cleaner Production 50:1-11.

McKay, G. 2011. Radical Gardening: Politics, Idealism \& Rebellion in the Garden. London: Frances Lincoln Limited.

Mendes, W., Balmer, K., Kaethler, T., and Rhoads, A. 2008. Using land inventories to plan for urban agriculture: experiences from Portland and Vancouver. Journal of the American Planning Association 74(4):435-449. 
Milbourne, P. 2012. Everyday (in)justices and ordinary environmentalisms: community gardening in disadvantaged urban neighbourhoods. Local Environment 17(9):943-957.

Miller, J. 2005. Biodiversity conservation and the extinction of experience. Trends in Ecology and Evolution 20(8):261-268.

Mintzberg, H., Ahlstrand, B., and Lampel, J. 1998. Strategy Safari. A Guided Tour Through the Wilds of Strategic Management. New York: Free Press.

Mougeot, L.J.A. 2006. Growing Better Cities: Urban Agriculture for Sustainable Development. Ottawa, Canada: International Development Research Center.

Nilsson, E.M. and Wiman, V. 2015. Gardening communities as urban archives and social resource in urban planning. In B. Westerlund, M. Tham, H. Edeholt, M. Ávila, L. Diedrich, J. Rosenquist, A. Holmquist, S. Maittinen, D. Stuedahl, P. Ullmark, K. Lindström, and Å Ståhl (eds). Nordes Design Ecologies : Challenging Anthropocentrism in the Design of Sustainable Futures. Stockholm, Sweden: Konstfack University College of Arts, Crafts and Design, pp. 1-4.

Prové, C., Joost, D., and de Kroma, M. 2016. Taking context into account in urban agriculture governance: case studies of Warsaw (Poland) and Ghent (Belgium). Land Use Policy 56:16-26.

Purcell, M. 2002. Excavating Lefebvre: the right to the city and its urban politics of the inhabitant. GeoJournal 58 (2-3), 99-108.

Purcell, M. and Tyman, S.K. 2014. Cultivating food as a right to the city. Local Environment 20(10):1132-1147.

Reynolds, R. 2008. On Guerilla Gardening: A Handbook for Gardening Without Boundaries. London: Bloomsbury.

Rosol, M. 2010. Public participation in post-Fordist urban green space governance: The case of community gardens in Berlin. International Journal of Urban and Regional Research 34(3): 548-563.

Rosol, M. 2012. Community volunteering as neoliberal strategy? Green space production in Berlin. Antipode 44(1):239-257.

SCB 2016. Statistics of population in Stockholm (online). Available at http://www.scb.se/sv_/hitta-statistik/statistikefter-amne/befolkning/befolkningens-sammansattning/befolkningsstatistik/ (Accessed 6 September 2016.

Schmelzkopf, K. 1995. Urban community gardens as a contested space. Geographical Review 85(3):364-381.

Seitz, J. 2011. Urban gardens: catalysts for restorative commons infrastructure. In L. Campbell and A. Wiesen (eds). Restorative Commons: Creating Health and Well-Being
Through Urban Landscapes. US: Agriculture Dept, pp. 96109.

Seyfang, G. and Smith, A. 2007. Grassroots innovations for sustainable development: towards a new research and policy agenda. Journal Environmental Politics 16(4):584-603.

Stockholm City 2016a. Statistik och fakta (Online). Available at http://www.stockholm.se/OmStockholm/Fakta-och-kartor/ (Accessed 21 May 2017).

Stockholm City 2016b. Brukaravtal -för dig som vill sköta ett område $i$ din egen närmiljö. (Online). Available at Website www.stockholm.se/Fristaende-webbplatser/Stadsdelssajter/ Ostermalm/Tillsammans/Odlingslador-2015-i-Tessin--ochOP-parken/Brukaravatal---for-dig-som-vill-skota-ett-omradei-din-egen-narmiljo/. (Accessed 3 October 2016).

Stockholm City 2017. Intresserad av stadsodling (Online). Available at Website www.stockholm.se/-/Nyheter/Parknatur-och-friluftsliv/Nm_Vill-du-stadsodla-i-Roda-bergen/ (Accessed 10 May 2017).

Teisman, G.R. 2000.. Models for research into decision-making processes: on phases, streams and decision-making rounds. Public Administration 78(4):937-956.

Tornaghi, C. 2012. Public space, urban agriculture and the grassroots creation of new commons: lessons and challenges for policy makers. In A.M. Viljoen, J.S.C. Wiskerke (eds). Sustainable Food Planning. Wageningen: Wageningen Academic Publisher, pp. 349-364.

Tornaghi, C. 2014. Critical geography of urban agriculture. Progress in Human Geography 38(4):551-567.

Tracey, D. 2007. Guerrilla Gardening: A Manualfesto. Gabriola Island (BC): New Society Publishers.

Trädgård på spåret 2017. (Online). Available at Website www. facebook.com/TRADGARDPASPARET/ (Accessed 4 April 2017).

United Nations 2016. (Online). Available at www.un.org/sustainabledevelopment/sustainable-development-goals/ (Accessed 23 May 2017).

Voicu, I. and Been, V. 2008. The effect of community gardens on neighboring property values. Real Estate Economics 36(2): 241-283.

Wakefield, S., Yeudall, F., Taron, C., Reynolds, J., and Skinner, A. 2007. Growing urban health: community gardening in South-east Toronto. Health Promotion International 22(2):92-101.

Whitehead, M. 2013. Neoliberal urban environmentalism and the adaptive city. Urban Studies 50(7):1348-1367. 